Book Review

\title{
Der Islam als Alternative
}

\section{By Murad Hoffmann. Munich: Eugen Diederichs Verlag, 1992, $214 \mathrm{pp}$.}

This small book-Islam as an Alternative - by the German ambassador to Morocco, which contains an excellent foreword by Annemarie Schimmel, is remarkable for various reasons. Public interest had already been heightened due to an earlier television interview with the author which, conducted in a very provocative manner, threw his continued diplomatic appointment into question. However, as German attention turned elsewhere, this issue declined in importance, making it possible for this very eloquent new Muslim to continue representing his country abroad.

Events in the Muslim world, such as the Iranian revolution and the Gulf war, often result in many misrepresentations of Islam in the Western media. But these same events also engender a never-ending series of invitations for religious dialogue by people of good will who are trying to understand what is happening and why Islam seems to spread despite its mainly negative image in the eyes of non-Muslims. However, Muslims face a problem here: there are few competent dialogue partners who can present accurately the Islamic side. While representatives of the Catholic and Protestant churches are efficiently trained and very well educated, Muslims in Germany are often unable to express fully and coherently their thoughts in German. They also usually have not received a proper Islamic education. Even if they enroll in a German university specifically for the purpose of acquiring such an education, they are nonetheless trained to look at their religion through non-Muslim eyes. And it is these very eyes that most often see Islam as "fundamentalist," "belligerent," and "backward, particularly as far as women are concerned," to name only the most important misconceptions.

Hoffmann's book is remarkable because it deals with many controversial issues head on, thereby providing handy answers and explanations for those involved in interfaith dialogue. Many new Muslims may have thought along the same lines in these matters, but to be able to present them in a few and absolutely to-the-point replies is another thing.

Here are some of these reizworte (emotive words), in an abbreviated form, together with what the author has to say about them.

Fundamentalism: "Each and every religion or ideology develops on some basics-called Bible, Gospel or 'Marx, Engels, and Lenin'-which are considered definable, concluded, unchangeable and able to support, that is as fundamentals. The same is true of Islam, the fundamentals of which are the 
Qur'an and the Sunna" (p. 87). Speaking of the challenges represented by time and circumstances and the resulting diversity of contemporary manifestations, the author says that all these "religions and ideologies have one thing in common: the trend to go back to its sources" (p. 88). He differentiates between "literal" and "rational" fundamentalists in Islam. The former, he says, keeps strictly to Qur'an 3:7-stating that only Allah knows the meaning of the allegorical verses-and they "take this to heart by humbly as well as intelligently renouncing metaphysics, theology and mystics" (p. 90). Rational fundamentalism appeared at the beginning of the twentieth century with the reform movement of the "Salafiyya" (go back to the past, take the forefathers as guiding example), as Hoffmann says. Though too apologetic in his opinion, he commends them for their attempt to reopen the door of ijtihad in order to understand Islam and the Qur'an in the light of contemporary circumstances. $\mathrm{He}$ also observes that it was not so much the religious scholars who led this movement, but rather the intelligentsia of the various scientific disciplines.

Tolerance and Violence: Citing from the Qur'an that Allah could have made humanity into one community had He so wished, but rather intended to put human beings on trial and let them compete with each other in doing good (5:48), and that "there is no compulsion in religion" (2:256), the author holds that from the very beginning Islam has worked for peaceful coexistence between Muslims and non-Muslims. But, as he reminds the reader, tolerance is prescribed not only vis-à-vis non-Muslims but also within the Islamic ummah:

Everyone should look after what is right in his own realm-in his family, in his factory, as head of state in his nation-but not arbitrarily at what is beyond so that not in a misunderstood integrism facistoid 'Islamic' political systems came into existence. May God prevent this even if such states consider themselves to be "theocratic." (p. 101)

Women in Society: The author admits that there is "no smoke without fire" and that, despite the fact that Muslim women were granted rights fourteen centuries ago-rights which, incidentally, women in other parts of the world were still fighting for at the turn of the twentieth century-theory is widely at variance with practice when it comes to Muslim male-female relationships. But Islam also sticks to the institution of marriage nowadays, just as much as in the time of the Prophet,

by acknowledging the different roles husband and wife have to shoulder. For Islam, man and woman share the same dignity but face varying tasks; they have the same value but different capacities; they enjoy the same status before God but have to play different roles in life. The question whether this is fashionable or not does not make any difference in 
judging. But then Islam is no fashionable movement. It can wait. (p. 172)

When writing about the much-disputed veil for Muslim women, he lets European women who regard this way as dressing as binding, speak:

These women are unanimous in their opinion that Western women have become sex objects due to the progressive trend of denudation and exposure to the unceasing pressure to dress more and more attractively. The Western Muslim woman who wears a veil because she wishes to be obedient to religious injunctions wants to be left in peace when she has to go out. She wants to behave in such a way that she earns God's good pleasure. She wants to emerge form the vicious circle and establish her dignity as a woman who-as a wifewishes to be available for her husband only and is no longer looking for a bridegroom. The Muslim woman with a veil says to those around: Look at my face, not my legs! . . . It is a protest against the conditions of life in contemporary Europe. (p. 182)

Hoffmann deals with other controversial topics, such as "Republic or Monarchy," "Islamic Market Economy," "Islam and the Environment," "Holy War," "Islamic Jurisprudence," "Christianity from the Islamic Point of View," and "Fatalism." Fatalism, for example, has long been wrongly associated in Western thought with Islam. This is a gross misconception persistently instilled in the minds of Western people-generation after generation. Hoffman clarifies the correct Islamic attitude in an interesting way:

Only when a Muslim has exerted himself to the utmost of his capabilities to realize a project and fails, or is struck by misfortune, does he assume the kismet attitude. Then he will neither despair nor pull out his hair or tear his clothes, but will come to understand and accept that what happened has been maktüb-that is "written for him." Therefore, fatalism is not concerned with the future but with what has already happened, with the past. (p. 85)

Hoffmann treats these topics with insight and profound knowledge and, perhaps most significantly of all, in such a brief and concise manner that readers are able to keep his points in mind so that they can be used whenever a competent and accurate answer to a given issue is required.

Fatima Grimm Al-Islam Magazine, Islamic Center Munich, Germany 